\title{
Penentuan Kriteria Pemilihan Strategi Sistem Manufaktur Menggunakan Analytic Hierarchy Process
}

\author{
Apriani Soepardi ${ }^{*}$, Puryani ${ }^{1}$, Mochammad Chaeron$^{1}$, Isti Anggraini $^{1}$
}

\begin{abstract}
This paper presents the decision making process for the selection of criteria manufacturing system using AHP. The accuracy of the selection strategy is based on many criteria that termed as agility capabilities. Several influential criteria that is used in the selection are responsiveness, product quality, product cost, operator skills, and inventory. From these criteria, manufacturing responsiveness has the highest priority weight. On these criteria, the company cast metal is required to have the agility capabilities in reduction of lead-time for product development, new product introduction, and a wide variety of products. While the criteria for product quality takes places at second priority, followed by product cost, operator skill and inventory. From agility capability priorities that must be owned by the company of cast metal, the manufacturing system according to the characteristics of the organization and be able to respond appropriately to environmental changes is lean manufacturing system.
\end{abstract}

Keywords: Analytic Hierarchy Process, agility capability, selection criteria, lean manufacturing system, priority, responsiveness.

\section{Pendahuluan}

Kondisi industri logam di Kecamatan Ceper, Kabupaten Klaten semakin memprihatinkan. Apalagi sejak Maret 2004, telah terjadi kenaikan harga bahan baku berupa besi scrap dan kokas. Persoalan baru muncul, yakni turunnya permintaan pasar yang antara lain disebabkan oleh ketidakmampuan menghasilkan produk yang presisi, tepat waktu, dan dalam volume yang besar. Padahal tren ke depan adalah industri yang mampu menghasilkan produk presisi yang layak jual baik di pasar lokal maupun global (Kompas [4]).

Faktor lain penyebab penurunan jumlah pesanan adalah menurunnya jumlah pembangunan yang membutuhkan peralatan logam, biaya transportasi bahan baku dan produk jadi sangat mahal akibat kenaikan BBM. Di sisi lain, perusahaan logam juga tergantung dengan bahan kimia yang harus diimpor. Adanya kenyataan bahwa nilai rupiah yang tidak menentu, perusahaan cor logam tidak mampu lagi mendapatkan bahan-bahan tersebut. Mahalnya harga kokas menyebabkan sebagian pengusaha beralih menggunakan sistem induksi dengan sumber energi listik. Pajak pemakaian listrik untuk industri cor logam sangat tinggi, sedangkan kredit UKM yang tidak menyentuh sektor riil menunjukkan lemahnya dukungan modal dari sektor perbankan (Kompas [5]). Permasalahan yang dihadapi industri cor logam semakin bertambah dengan tidak adanya

\footnotetext{
${ }_{1}$ Fakultas Teknologi Industri, Jurusan Teknik Industri, Universitas Pembangunan Nasional Veteran Yogjakarta. J. Babarsari 2 Tambakbayan, Yogjakarta 55281. Email: apriani.soepardi@ gmail.com; purya_ni@yahoo.co.id; m.chaeron@upnyk.ac.id.

*Penulis korespondensi
}

kebijakan pemerintah untuk proteksi produk dalam negeri, terlebih setelah pasar bebas terbuka lebar (Radar Solo [7]).

Sudah saatnya kinerja sektor industri manufaktur cor logam harus ditingkatkan. Untuk mencapai kinerja yang baik, sentra industri cor logam Ceper perlu mengadopsi sistem manufaktur yang tepat dengan serangkaian strategi efektif yang menjadi karakteristik dari sistem tersebut. Oleh karena itu dalam penelitian ini akan dilakukan penentuan kriteria dan pemilihan strategi sistem manufaktur cerdas yang tepat, yaitu sesuai dengan karakteristik, kebutuhan dan kemampuan perusahaan, sehingga diharapkan mampu memberikan solusi perbaikan untuk sektor industri cor logam agar mampu bertahan dan dalam jangka panjang dapat berkembang dalam situasi lingkungan bisnis yang bersifat turbulen. Pada akhirnya kondisi ini ditujukan untuk peningkatan daya saing industri cor logam itu sendiri.

Kajian tentang sistem manufaktur cerdas telah banyak diteliti dan diterapkan pada sektor industri manufaktur. Yusuf et al. [14] telah mengkaji pemahaman tentang kecerdasan (agility) dari berbagai macam perspektif dan menyarankan definisi komprehensif yang dapat diadopsi sebagai definisi kerja oleh para praktisi. Definisi kerja tersebut memunculkan empat konsep inti kecerdasan, yaitu manajemen kompetensi inti, pembentukan perusahaan virtual, kemampuan rekonfigurasi dan pengetahuan sebagai pendorong perusahaan.

Sharifi dan Zhang [10] telah membangun sebuah metodologi untuk mencapai kecerdasan dalam suatu organisasi manufaktur. Metodologi tersebut didasar- 
kan pada model konseptual bahwa kecerdasan terdiri atas tiga elemen, yaitu: perubahan dan tekanan dari lingkungan bisnis yang mengharuskan organisasi perusahaan harus mencari cara-cara baru untuk mempertahankan keunggulan bersaingnya (agility drivers), kemampuan penting yang diperlukan perusahaan dalam rangka merespon perubahan dan mengambil keuntungan dari tekanan tersebut (agility capabilities), dan praktek/metode/cara/teknik yang telah dimiliki dan dipilih oleh organisasi untuk mewujudkan kemampuan cerdasnya (agility providers). Kemampuan penting yang kemudian disebut sebagai kemampuan cerdas tersebut terdiri atas empat aspek, yaitu daya tanggap (responsiveness), kompetensi, fleksibilitas, dan kecepatan (speed/ quickness). Mengacu pada model konseptual tersebut, diusulkan sebuah metodologi untuk mencapai kecerdasan. Metodologi ini dimulai dari identifikasi ketiga elemen kecerdasan, analisis celah antara kebutuhan kecerdasan dan tingkat kecerdasan yang dimiliki sekarang, perumusan strategi, yang dilanjutkan dengan implementasi dan berakhir pada pengukuran kinerja hasil penerapan kemampuan cerdas tersebut.

Elkins et al. [2] mengusulkan dua model keputusan sederhana yang memberikan wawasan awal dan perspektif industri dalam kaitannya dengan investasi sistem manufaktur cerdas. Model ini diaplikasikan pada keputusan untuk memilih kelayakan investasi pada tiga jenis sistem manufaktur, yaitu dedicated manufacturing system (DMS), agile manufacturing system (AMS), dan flexible manufacturing system (FMS).

Abdi dan Labib [1] menggunakan model Analytic Hierarchy Process (AHP) untuk menstrukturisasikan proses pengambilan keputusan dalam rangka pemilihan sistem manufaktur di antara alternatif yang layak pada kajian reconfigurable manufacturing system (RMS). Tujuan strategis menuju perancangan RMS diidentifikasi terdiri atas: daya tanggap, biaya produk, kualitas produk, persediaan, dan ketrampilan operator. Kriteria daya tanggap ditekankan dalam model AHP ini sebagai tujuan ekonomis baru bersama dengan kriteria lain. Mereka mempertimbangkan daya tanggap sebagai kemampuan dalam menggunakan sumber daya yang ada untuk menghadapi perubahan lingkungan dan teknologi baru secara cepat. Semua parameter dalam model ini disusun dalam lima tingkat, yaitu: Jangka waktu perencanaan, pengambil keputusan (aktor), tujuan pengambil keputusan, kriteria yang memenuhi tujuan tersebut, dan alternatif/ keputusan.

\section{Metode Penelitian}

Pada penelitian ini, pendekatan penelitian yang digunakan mengacu pada model konseptual kecerdasan yang diusulkan oleh Sharifi dan Zhang [10]. Tujuan akhir (goal) proses pengambilan keputusan pada kajian ini adalah strategi sistem manufaktur terbaik bagi industri cor logam Ceper. Parameter strategis kriteria dan sub-kriteria dalam proses penentuan sistem manufaktur diambil dari Abdi dan Labib [1] dengan hanya menggunakan tiga tingkat, yaitu: tingkat tujuan, kriteria, dan keputusan.

Penggunaan AHP hanya pada penentuan kriteria dan sub kriteria. Pada pemilihan strategi sistem manufaktur tidak menggunakan AHP tetapi menggunakan kesesuaian sub kriteria dengan ciri-ciri strategi sistem manufaktur. Kriteria dan sub-kriteria tersebut dipertimbangkan sebagai karakteristik yang menggambarkan kemampuan cerdas yang diperlukan perusahaan dalam merespon perubahan lingkungan dan untuk mengambil keuntungan dari terjadinya perubahan tersebut, sebagai berikut:

1) Daya tanggap atau kemampuan reaksi (R). Kemampuan reaksi dihubungkan dengan kemampuan sistem manufaktur untuk menggunakan sumber daya yang ada untuk merespon dengan cepat dan tepat perubahan lingkungan yang tidak menentu, baik yang sudah diprediksi sebelumnya maupun yang tidak diperkirakan sebelumnya. Empat sub-kriteria diturunkan dari kriteria ini, meliputi:

a. Variasi produk (r1); kemampuan untuk memproduksi berbagai produk dengan kebutuhan proses yang berbeda.

b. Introduksi produk baru (r2); kemampuan untuk menerima rancangan baru suatu produk.

c. Kecepatan respon untuk mengubah product family menggunakan fasilitas yang ada (r3); kemampuan lantai produksi untuk mengubah kapasitas dan fungsionalitas dengan reusability maksimal dalam memenuhi fluktuasi permintaan.

d. Reduksi lead time untuk pengembangan produk (r4); kemampuan untuk mengubah alat yang digunakan memproduksi suatu produk campuran dalam satu family dengan ramp-up dan set-up time yang rendah.

2) Biaya produk (C). Biaya produk dapat dibagi dalam sub-kriteria:

a. Biaya bahan baku (c1), termasuk semua bahan langsung yang digunakan dalam proses manufaktur.

b. Biaya proses (c2), terdiri dari biaya investasi modal pada peralatan manufaktur dan biaya operasional, seperti biaya utilisasi mesin, ongkos operator yang menjalankan mesin, dan upah pekerja pada lantai produksi yang bertanggung jawab pada tugas selain proses produksi (misal: teknisi perawatan, transportasi, pengendalian kualitas, dan pembersihan). 
c. Biaya tidak langsung (c3) terdiri dari energi, engineers, dan tenaga administrasi, dan lainlain.

3) Kualitas produk (Q). Kualitas produk adalah karakteristik produk seperti ukuran, berat, bentuk, model, fungsi, dan sebagainya yang sesuai dengan spesifikasi yang diinginkan dan standar yang ditetapkan. Agar didapatkan kualitas produk yang terjamin perlu dilakukan pengujian dan pemeriksaan pada kualitas bahan baku, proses, dan produk jadi secara bertahap dan teratur. Sub-kriterianya meliputi:

a. Kualitas bahan baku (q1) yang difokuskan pada kualitas masukan bahan baku yang dibeli.

b. Kualitas proses (q2) yang ditekankan pada kualitas work-in-progess dalam aliran manufaktur.

c. Produk akhir (q3) yang memberikan perhatian pada kualitas item jadi yang siap untuk dikirimkan.

4) Persediaan (I). Persediaan adalah bahan baku, bahan setengah jadi, maupun produk jadi yang menunggu dalam gudang penyimpanan untuk diproses maupun dikirim ke konsumen. Persediaan bahan baku, persediaan di bagian proses, dan persediaan produk jadi yang dimiliki akan menimbulkan biaya simpan. Sub-kriterianya meliputi:

a. Persediaan bahan baku (i1) yang merupakan persediaan bahan mentah di gudang untuk dikirim ke lantai produksi.

b. Work in progress (i2), yaitu persediaan di bagian proses yang menumpuk sebelum proses produksi selesai dikerjakan.

c. Produk jadi (i3) adalah persediaan produk sebelum dikirim ke konsumen.

5) Keterampilan operator (O). Keterampilan operator adalah kemampuan dari operator untuk dapat melaksanakan dan menyesuaikan tugasnya menggunakan peralatan dan mesin yang ada. Dorongan perusahaan terhadap operator, perlunya perusahaan mengubah sistem yang telah ada di perusahaan, kemampuan operator menyesuaikan pekerjaannya setelah diberikan pelatihan, persentase peningkatan produktivitas setelah operator diberikan pelatihan, dan kemampuan operator dalam menggunakan fasilitas berteknologi tinggi sangat diperlukan bagi kelangsungan dan kemajuan perusahaan. Subkriterianya meliputi:

a. Motivasi (o1) merupakan semua faktor yang mendorong operator untuk berusaha ekstra aktif untuk mengubah sistem sesuai dengan strategi yang tepat (reconfiguring system).

b. Pelatihan ( 02 ) yang merupakan fasilitas yang diberikan kepada operator berupa proses pembelajaran untuk menyesuaikan tugasnya sesuai dengan strategi sistem manufaktur yang diterapkan.

c. Jenis fasilitas (o3) adalah hal-hal yang mempengaruhi pada kebutuhan keterampilan. Misalnya penggunaan antara mesin singlepurpose dan fleksibel akan menimbulkan kebutuhan tenaga kerja dengan tingkat ketrampilan yang berbeda.

Untuk penentuan alternatif dalam penyusunan hirarki ini didasarkan atas beberapa strategi sistem manufaktur yang mendekati kondisi nyata industri cor logam Ceper dengan acuan berdasarkan studi kasus Abdi dan Labib [1]. Pada level alternatif, mereka menggunakan tiga macam alternatif, yaitu: Existing Manufacturing System (EMS), RMS, dan Hybrid Manufacturing System (HMS). Pada penelitian ini, level alternatif melibatkan tiga strategi sistem manufaktur dalam EMS saja, yaitu DMS, Cellular Manufacturing System (CMS), dan Lean Manufacturing System (LMS).

\section{Dedicated Manufacturing System (Emiracle [3])}

Sistem manufaktur ini termasuk dalam golongan sistem manufaktur tradisional yang yang dirancang untuk memproduksi satu tipe produk saja dengan volume tinggi tetapi sifat permintaannya deterministik. Biasanya mesin dan peralatan produksi yang digunakan relatif tetap (fixed-manufacturing system). Beberapa karakteristik utama DMS adalah sebagai berikut: peralatan kaku yang dirancang untuk memenuhi kebutuhan produk dengan jumlah jenis yang relatif terbata, tingkat produksi tinggi, keterampilan rendah, manajemen mudah, investasi rendah, dan kapasitas berlebih karena kecilnya permintaan dimana tidak dapat digunakan untuk memproduksi produk yang berbeda.

Machining center menjadi salah satu alternatif yang lebih ekonomis untuk produksi item yang cukup bervariasi. Beberapa keuntungan dari machining center adalah mengurangi atau menghilangkan non-cutting time, memproduksi lebih banyak item, penyelesaian permukaan lebih baik, dan respon yang cepat untuk melakukan perubahan.

\section{Cellular Manufacturing System (CMS)}

CMS adalah sebuah sistem manufaktur dimana peralatan dan stasiun kerja diatur dalam satu area yang memungkinkan gerakan kontinu dan kelancaran persediaan serta bahan untuk menghasilkan produk serupa dari awal sampai akhir dalam aliran proses tunggal (Singh dan Rajamani [12]). CMS melibatkan proses sebuah kumpulan item yang berada dalam satu family. 
Beberapa kelebihan CMS adalah mengurangi waktu set-up, mengurangi persediaan dalam proses, meningkatkan kualitas produk, lead time lebih rendah, mengurangi permintaan peralatan, meningkatkan produktivitas, pengendalian operasi keseluruhan yang baik. Jika diterapkan dengan benar, manfaat dari manufaktur selular meliputi: efisiensi produksi yang lebih tinggi, penghapusan limbah, penurunan tingkat persediaan, mengoptimalkan penggunaan lantai produksi, siklus produksi yang lebih singkat, kapasitas produksi yang lebih efektif, waktu respons pelanggan yang meningkat. Akibatnya semua biaya produksi menjadi lebih rendah dan keuntungan menjadi lebih besar. Menurut Abdi dan Labib [1] beberapa kekurangan CMS dari sudut pandang rekonfigurasi dapat dijelaskan sebagai berikut: penggunaan mesin rendah dan tidak seimbang karena terjadi duplikasi mesin yang sama di sel berbeda, fleksibilitas rendah untuk variasi produk, biaya perubahan sistem kerja tinggi untuk rekonfigurasi sel, contohnya relokasi mesin, pembatasan pada pengenalan sebuah produk baru karena potensi operasional yang tidak sama dengan produk yang ada.

Dalam CMS, pekerja didorong untuk berfikir kreatif tentang masalah produksi dan diberikan kebebasan untuk merencanakan, mengkoordinasikan, dan mengendalikan tugas mereka selama mereka memenuhi standar kualitas perusahaan, volume, waktu, dan biaya. Hal ini dimaksudkan agar tanggung jawab yang besar dan pekerjaan yang menantang mampu memotivasi pekerja untuk terus belajar dan memperbaiki prestasi yang telah didapat sebelumnya. Bila pekerja rutin untuk mempelajari keterampilan baru dan adanya pelatihan, mereka dapat dengan mudah dialihkan ke pekerjaan lain dalam sel atau produksi unit lain yang berbeda. Cellular manufaktur mempengaruhi pekerja dalam beberapa cara baik manajemen diri, motivasi, masukan dari karyawan, pengawasan, dan kohesivitas kelompok (Siliconfearest [11]).

\section{Lean Manufacturing System}

Dalam Sanchez dan Perez [9] dinyatakan bahwa lean manufacturing merupakan suatu filosofi manufaktur yang memperpendek waktu antara pesanan pelanggan dan pengiriman barang dengan menghilangkan sumber waste. Waktu proses akan semakin pendek dengan menghilangkan waste, dalam kenyataannya, apabila lead time diperpendek dan memfokuskan pada fleksibilitas produksi, maka akan berdampak pada peningkatan kualitas produk yang lebih tinggi, respon pelanggan yang lebih baik, produktivitas yang lebih tinggi, dan pemanfaatan peralatan maupun tempat yang lebih efisien.
Berdasarkan uraian dari kriteria dan sub-kriteria di atas, pemilihan alternatif sistem manufaktur dapat disusun menggunakan sebuah hirarki untuk mempermudah analisis penyelesaiannya. Penyusunan hirarki untuk pemilihan sistem manufaktur dapat ditunjukkan pada Gambar 1.

Tiga puluh perusahaan dijadikan sampel dalam penelitian ini. Tujuh perusahaan berbentuk Perseroaan Terbatas (PT) dan sisanya berbentuk Perseroan Comanditer (CV). Pemilihan responden berdasarkan pertimbangan aktor utama yang terlibat dalam pengambilan keputusan sistem produksi. Pada beberapa perusahaan yang berbentuk PT, yang menjadi responden adalah manajer produksi dan manajer gudang, sehingga total jumlah responden sebanyak 34 orang.

Pengolahan data dimulai dari penghitungan skor hasil kuesioner yang telah diisi oleh responden. Skor dijumlahkan untuk setiap pertanyaan kemudian dihitung persentasenya. Perhitungan persentase didapatkan dari nilai rata-rata skor pada masingmasing sub kriteria terhadap nilai maksimal. Persentase ini menunjukkan tingkat kemampuan yang telah dimiliki oleh perusahaan, menurut Sharifi dan Zhang [10] disebut sebagai agility provider. Berdasarkan Taj [13] nilai skor 0-19\% dikategorikan sangat buruk; skor 20-39\% buruk, 40$59 \%$ sedang; $60-79 \%$ baik; dan $80-100 \%$ sangat baik. Hasil rekapitulasi persentase sub kriteria pada Tabel 1.

Evaluasi sub-kriteria untuk masing-masing kriteria didapatkan dari hasil rata-rata skor kuesioner yang telah diperoleh sebelumnya. Tabel 2 merupakan hasil perhitungan nilai relatif sub-kriteria yang akan digunakan untuk mencari prioritas akhir subkriteria setelah dikalikan dengan bobot masingmasing kriteria.

Penentuan ranking kriteria digunakan untuk mengetahui urutan prioritas setiap kriteria yang telah disesuaikan dengan kondisi sentra industri cor logam. Berdasarkan hasil wawancara dengan para responden diperoleh urutan atau ranking dari setiap kriteria yang digunakan seperti yang ditunjukkan pada Tabel 3. Ranking ini selanjutnya digunakan untuk pertimbangan dalam penentuan matrik perbandingan berpasangan (pairwise comparison) untuk setiap kriteria.

Berdasarkan hasil normalisasi dari matriks perbandingan berpasangan, bobot prioritas kriteria dihitung dengan melakukan penilaian relatif sel dengan jumlah pada tiap kolomnya. Selanjutnya pada tiap kriteria secara horizontal dijumlahkan dan diratarata atau dibagi dengan jumlah kriteria yang ada untuk mendapatkan bobot prioritasnya. Hasil perhitungan bobot kriteria pada Tabel 4 . 


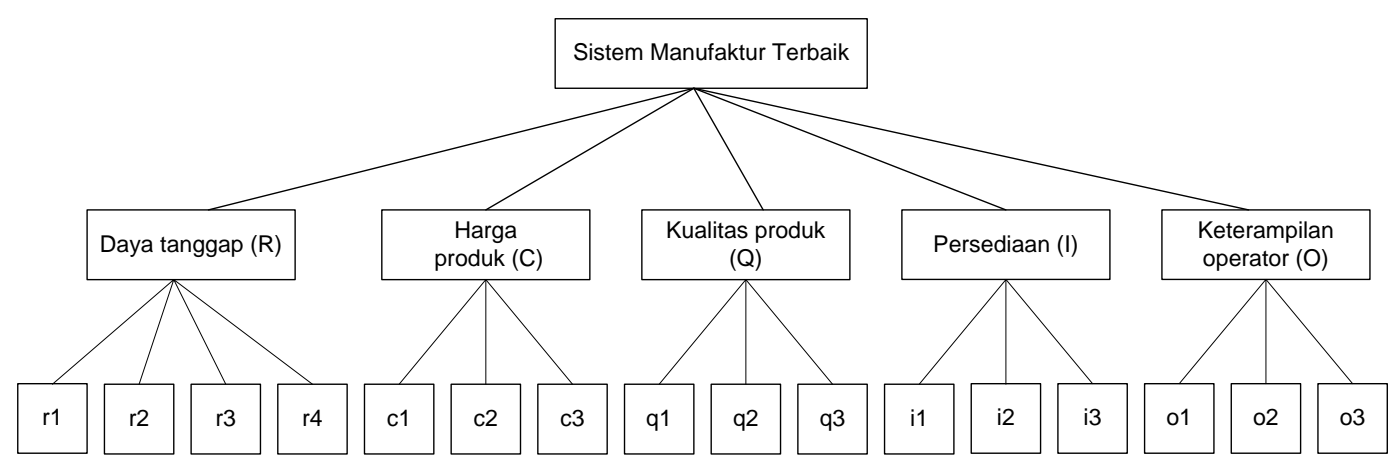

Gambar 1. Hirarki penentuan kriteria dan sub kriteria sistem manufaktur

Tabel 1. Hasil rekapitulasi persentase sub-kriteria

\begin{tabular}{ccccccc}
\hline No. & Kriteria & Sub kriteria & Total skor & Rata-rata skor & Persentase (\%) & Kategori \\
\hline & & $\mathrm{r} 1$ & 9,29 & 3,09 & 61,96 & baik \\
1. & Daya tanggap atau & $\mathrm{r} 2$ & 10,29 & 3,43 & 68,62 & baik \\
& kemampuan reaksi (R) & $\mathrm{r} 3$ & 5,14 & 2,57 & 51,47 & sedang \\
& & $\mathrm{r} 4$ & 9,00 & 4,50 & 90,00 & sangat baik \\
& & $\mathrm{c} 1$ & 8,35 & 4,17 & 83,52 & sangat baik \\
2. & Harga produk (C) & $\mathrm{c} 2$ & 3,67 & 3,64 & 72,94 & baik \\
& & $\mathrm{c} 3$ & 8,76 & 2,92 & 58,43 & sedang \\
& & $\mathrm{q} 1$ & 6,64 & 3,32 & 66,47 & baik \\
3. & Kualitas produk (Q) & $\mathrm{q} 2$ & 7,29 & 3,64 & 72,94 & baik \\
& & $\mathrm{q} 3$ & 11,42 & 3,80 & 76,08 & baik \\
& & $\mathrm{i} 1$ & 6,58 & 3,29 & 65,88 & baik \\
4. & Persediaan (I) & $\mathrm{i} 2$ & 4,08 & 4,08 & 81,76 & sangat baik \\
& & $\mathrm{i} 3$ & 9,88 & 3,29 & 65,88 & baik \\
& & $\mathrm{o} 1$ & 7,94 & 3,97 & 79,41 & baik \\
5. & Keterampilan operator (O) & $\mathrm{o} 2$ & 6,70 & 3,35 & 67,06 & baik \\
& & $\mathrm{o} 3$ & 7,35 & 3,67 & 73,52 & baik \\
\hline
\end{tabular}

Tabel 2. Nilai relatif setiap sub-kriteria

\begin{tabular}{|c|c|c|c|c|c|c|c|c|c|c|c|c|c|c|}
\hline Sk & $\begin{array}{c}\text { Skor } \\
\text { R }\end{array}$ & $\frac{R_{i}}{\sum_{i} R_{i}}$ & Sk & Skor C & & Sk & Skor Q & & Sk & Skor I & & Sk & Skor O & \\
\hline $\mathrm{r} 1$ & 3,1 & 0,227 & $\mathrm{c} 1$ & 4,2 & 0,392 & q1 & 3,3 & 0,308 & i1 & 3,3 & 0,308 & o1 & 4 & 0,360 \\
\hline r2 & 3,4 & 0,250 & c2 & 3,6 & 0,336 & q2 & 3,6 & 0,336 & i2 & 4,1 & 0,383 & o2 & 3,4 & 0,306 \\
\hline r3 & 2,6 & 0,191 & c3 & 2,9 & 0,271 & q3 & 3,8 & 0,355 & i3 & 3,3 & 0,308 & o3 & 3,7 & 0,333 \\
\hline $\mathrm{r} 4$ & 4,5 & 0,330 & & & & & & & & & & & & \\
\hline Total & 13,6 & & & 10,7 & & & 10,7 & & 1 & 10,7 & & & 11,1 & \\
\hline
\end{tabular}

Tabel 3. Ranking kriteria berdasarkan expert judgement

\begin{tabular}{lc}
\hline \multicolumn{1}{c}{ Kriteria } & Ranking \\
\hline Daya tanggap (R) & 1 \\
Kualitas produk (Q) & 2 \\
Biaya produk (C) & 3 \\
Keterampilan operator (O) & 4 \\
Persediaan (I) & 5 \\
\hline
\end{tabular}

Tabel 4. Hasil perhitungan bobot kriteria

\begin{tabular}{cccccccc}
\hline MS & $\mathrm{R}$ & $\mathrm{C}$ & $\mathrm{Q}$ & $\mathrm{I}$ & $\mathrm{O}$ & Jumlah & $\begin{array}{c}\text { Bobot } \\
(\mathrm{W})\end{array}$ \\
\hline $\mathrm{R}$ & 0,438 & 0,439 & 0,490 & 0,333 & 0,381 & 2,081 & 0,416 \\
$\mathrm{C}$ & 0,146 & 0,146 & 0,122 & 0,200 & 0,190 & 0,804 & 0,161 \\
$\mathrm{Q}$ & 0,219 & 0,293 & 0,245 & 0,267 & 0,286 & 1,310 & 0,262 \\
$\mathrm{I}$ & 0,088 & 0,049 & 0,061 & 0,067 & 0,048 & 0,313 & 0,063 \\
$\mathrm{O}$ & 0,109 & 0,073 & 0,082 & 0,133 & 0,095 & 0,492 & 0,098 \\
\hline Total & 1 & 1 & 1 & 1 & 1 & 5 & 1 \\
\hline
\end{tabular}

Tabel 5. Hasil perhitungan nilai prioritas akhir sub-kriteria

\begin{tabular}{cccccccccc}
\hline Sub kriteria & $\frac{R_{i}}{\sum_{i} R_{i}} W_{R}$ & Sub kriteria & $\frac{C_{i}}{\sum_{i} C_{i}} W_{C}$ & Sub kriteria & $\frac{Q_{i}}{\sum_{i} Q_{i}} W_{Q}$ & Sub kriteria & $\frac{l_{i}}{\sum_{i} l_{i}} W_{l}$ & Sub kriteria & $\frac{O_{i}}{\sum_{i} O_{i}} W_{O}$ \\
\hline $\mathrm{r} 1$ & 0,0948 & $\mathrm{c} 1$ & 0,0632 & $\mathrm{q} 1$ & 0,0808 & $\mathrm{i} 1$ & 0,0194 & $\mathrm{o} 1$ & 0,0353 \\
$\mathrm{r} 2$ & 0,1040 & $\mathrm{c} 2$ & 0,0542 & $\mathrm{q} 2$ & 0,0881 & $\mathrm{i} 2$ & 0,0241 & $\mathrm{o} 2$ & 0,0300 \\
$\mathrm{r} 3$ & 0,0795 & $\mathrm{c} 3$ & 0,0436 & $\mathrm{q} 3$ & 0,0930 & $\mathrm{i} 3$ & 0,0194 & $\mathrm{o} 3$ & 0,0327 \\
$\mathrm{r} 4$ & 0,1377 & & & & & & & & \\
\hline
\end{tabular}


Pengujian konsistensi terhadap perbandingan antar elemen pada tiap tingkat hirarki dilakukan untuk memastikan bahwa urutan prioritas yang dihasilkan tersebut didapatkan dari rangkaian perbandingan yang masih berada dalam batas-batas preferensi yang logis (Saaty [8]). Hasil pengujian konsistensi indeks pada pengolahan data penelitian ini sebesar 0,017. Sedangkan untuk menguji konsistensi menyeluruh dari berbagai pertimbangan digunakan uji konsistensi rasio, dengan cara membagi nilai konsistensi indeks dengan nilai random index. Nilai konsistensi rasio yang diperoleh sebesar 0,0152 (kurang dari 0,1) yang berarti isian matriks perbandingan berpasangan masih berada dalam batas-batas konsistensi.

Penentuan nilai prioritas diperoleh dari hasil perkalian nilai bobot setiap kriteria dengan nilai relatif sub-kriteria dari perhitungan evaluasi tiap sub-kriteria. Hasil perhitungan nilai prioritas pada Tabel 5. Selanjutnya hasil yang diperoleh diurutkan berdasarkan peringkat nilai terbesar ke nilai terkecil.

\section{Hasil dan Pembahasan}

Kemampuan cerdas yang dimaksud pada kajian ini adalah suatu konsep yang menggambarkan kemampuan esensial yang harus diadopsi perusahaan dalam menghadapi perubahan lingkungan menuju perancangan strategi sistem manufaktur yang tepat. Hasil dari penelitian ini menunjukkan bahwa kemampuan cerdas yang berupa daya tanggap menempati ranking paling tinggi. Tiga dari empat sub-kriteria daya tanggap berada pada prioritas tertinggi yang kemudian disusul oleh kriteria kualitas, biaya produk, ketrampilan operator, dan persediaan (Tabel 6).

Sharifi dan Zhang [10] menguraikan secara bebas empat kriteria kemampuan cerdasnya dalam 20 macam sub-kriteria. Arti bebas di sini adalah bahwa sub-kriteria ini tidak dikelompokkan berdasarkan empat kriteria tersebut yang kemudian dua puluh macam kemampuan ini diberi ranking atau prioritas kepentingan dalam usaha mencapai kecerdasan dalam suatu perusahaan. Hasil perankingan kemampuan cerdas tersebut menunjukkan bahwa kemampuan daya tanggap merupakan kriteria yang paling penting dalam strategi sistem manufaktur cerdas. Lima kemampuan dari ranking 10 besar, yaitu ranking $1,3,4,7$, dan 10 dikategorikan sebagai kriteria daya tanggap (Tabel 7).

Penggunaan model AHP dalam penelitian ini hanya untuk mendapatkan bobot prioritas, dimana setiap kriteria dan sub-kriteria kemampuan cerdas dapat terkuantifikasi, sehingga lebih mudah dalam pengambilan keputusan yaitu untuk memprioritaskan strategi apa yang harus dipilih dan diterapkan ter- lebih dahulu. Akan tetapi untuk penelitian selanjutnya perlu dilakukan penambahan kriteria kecepatan yang melibatkan aspek waktu pengiriman produk, waktu proses, dan recovery time, sehingga diharapkan dapat diperoleh gambaran lebih rinci tentang kemampuan yang harus dipenuhi oleh organisasi perusahaan. Selain itu, kriteria kompetensi juga belum dilibatkan dalam penelitian ini berikut dengan pendefinisian dan pengkategorian sub kriterianya.

Analisis selanjutnya yaitu analisis kesesuaian antara kemampuan cerdas yang diperlukan perusahaan dengan kemampuan yang dimiliki perusahaan untuk menghadapi perubahan lingkungan yang sangat cepat dan sering tidak diharapkan. Berdasarkan Tabel 6 maka prioritas 1 sampai 6 sesuai dengan ciri-ciri LMS. Ada tiga ciri utama perusahaan yang menerapkan sistem ini yaitu: kecepatan produksi diatur sedemikian rupa sesuai dengan permintaan pelanggan (tidak berdasarkan cycle time, melakukan produksi jika diminta oleh pelanggan (dikenal dengan istilah pull system yaitu berproduksi sebanyak unit yang diminta pelanggan), dan melakukan produksi unit per unit mulai dari awal hingga akhir. Tujuannya adalah untuk menghindari bertumpuknya barang setengah jadi (WIP) di antara proses yang ada (Putri [6]).

DMS adalah sistem yang dirancang untuk meminimalkan waktu pengolahan dan tepat waktu tetapi produk yang dihasilkan berupa family produk yang sangat terbatas tetapi tingkat produksi tinggi. Sistem ini tidak sesuai diterapkan dalam industri cor logam karena produk yang dihasilkan industri cor logam sangat bervariasi dan jumlah sesuai permintaan konsumen. Kemampuan cerdas dari prioritas 7 sampai dengan 10 merupakan ciri-ciri dari DMS.

Tabel 6. Hasil perankingan sub-kriteria akhir

\begin{tabular}{|c|c|c|}
\hline Sub kriteria & $\begin{array}{c}\text { Nilai } \\
\text { prioritas }\end{array}$ & $\begin{array}{c}\text { Ranki } \\
\text { ng }\end{array}$ \\
\hline $\begin{array}{l}\text { Mengurangi lead time untuk } \\
\text { pengembangan produk (r4) }\end{array}$ & 0,1377 & 1 \\
\hline Pengenalan produk baru (r2) & 0,1040 & 2 \\
\hline Produk yang bervariasi (r1) & 0,0948 & 3 \\
\hline Kualitas produk akhir (q3) & 0,0930 & 4 \\
\hline Kualitas proses (q2) & 0,0881 & 5 \\
\hline Kualitas bahan baku (q1) & 0,0808 & 6 \\
\hline $\begin{array}{l}\text { Tanggapan cepat untuk } \\
\text { mengubah permintaan dengan } \\
\text { fasilitas yang ada (r3) }\end{array}$ & 0,0795 & 7 \\
\hline Biaya bahan baku (c1) & 0,0632 & 8 \\
\hline Biaya proses (c2) & 0,0542 & 9 \\
\hline Biaya tidak langsung (c3) & 0,0436 & 10 \\
\hline Motivasi (o1) & 0,0353 & 11 \\
\hline Jenis fasilitas (o3) & 0,0327 & 12 \\
\hline Pelatihan (o2) & 0,0300 & 13 \\
\hline Work in progress (i2) & 0,0241 & 14 \\
\hline Persediaan bahan baku (i1) & 0,0194 & 15 \\
\hline Persediaan produk jadi (i3) & 0,0194 & 16 \\
\hline
\end{tabular}


Tabel 7. Kemampuan yang diprioritaskan untuk mencapai agility dalam perusahaan (Sharifi dan Zhang, [10])

\begin{tabular}{|c|c|c|}
\hline Capabilities & Rank & Company's degree of ability \\
\hline 1. Sensing, perceiving, and anticipating changes & 1 & 6,4 \\
\hline 2. Product model/ configuration flexibility & 2 & 7,5 \\
\hline 3. Immediate reaction to change by effecting them into systems & $\overline{3}$ & 6,4 \\
\hline 4. Appropriate technology (hard and soft), or sufficient technological ability & 4 & 7,0 \\
\hline 5. Strategic vision & 5 & 6,3 \\
\hline 6. Cooperation (internal and external), (joint venture, virtual organization) & 6 & 5,0 \\
\hline 7. Change management & 7 & 6,9 \\
\hline 8. Products/services quality & 8 & 6,3 \\
\hline 9. Products and services delivery quickness and timeliness & 8 & 7,5 \\
\hline 10. Quick new products time to market & 9 & 8,5 \\
\hline 11. Cost effectiveness & 9 & 5,5 \\
\hline 12. Operations efficiency and effectiveness (leanness) & 10 & 6,6 \\
\hline 13. People flexibility & 11 & 8,0 \\
\hline 14. Knowledgeable, competent, and empowered people & 11 & ? \\
\hline 15. Fast operations time & 12 & - \\
\hline 16. Recovery from change & 13 & - \\
\hline 17. Organization and organizational issues flexibility & 14 & - \\
\hline 18. Integration & 15 & - \\
\hline 19. High rate of new products introduction & 15 & - \\
\hline 20. Product volume flexibility & 16 & - \\
\hline
\end{tabular}

Tabel 8. Analisis prioritas agility untuk LS

\begin{tabular}{|c|c|c|c|c|}
\hline Prioritas & Kriteria & Agility capability & Agitility provider & Solusi potensial \\
\hline 1 & $\begin{array}{l}\text { Kemampuan } \\
\text { reaksi (R) 0,416 }\end{array}$ & $\begin{array}{l}\text { Mengurangi lead } \\
\text { time untuk } \\
\text { pengembangan } \\
\text { produk (r4) } \\
\text { Nilai prioritas: } \\
0,1377\end{array}$ & $\begin{array}{l}\text { Skor: 90\%. Ranking: sangat baik } \\
\text { - Proses pembentukan produk terutama } \\
\text { machining menjadi kegiatan yang banyak } \\
\text { menghabiskan waktu. } \\
\text { - Perusahaan sangat menekankan arti } \\
\text { pentingnya kepuasan pelanggan karena da- } \\
\text { pat menjaga kelangsungan dan kemajuan } \\
\text { perusahaan } \\
\text { - Perusahaan berusaha mengurangi lead } \\
\text { time dengan menghilangkan pemborosan } \\
\text { (waste) dan melakukan efisiensi di semua } \\
\text { bagian. }\end{array}$ & $\begin{array}{l}\text { - Dalam industri, pengurangan lead time } \\
\text { merupakan bagian penting dari lean } \\
\text { manufacturing } \\
\text { - Prinsip lean manufacturing apabila lead } \\
\text { time diperpendek dan memfokuskan pada } \\
\text { fleksibilitas produksi, maka akan } \\
\text { didapatkan kualitas produk yang lebih } \\
\text { tinggi, respon pelanggan yang lebih baik, } \\
\text { produktivitas lebih banyak, dan } \\
\text { pemanfaatan peralatan maupun tempat } \\
\text { yang lebih efisien dengan menghilangkan } \\
\text { waste. }\end{array}$ \\
\hline 2 & $\begin{array}{l}\text { Kemampuan } \\
\text { reaksi }(\mathrm{R}) \\
0,416\end{array}$ & $\begin{array}{l}\text { Pengenalan } \\
\text { produk baru (r2) } \\
\text { Nilai prioritas: } \\
0,1040\end{array}$ & $\begin{array}{l}\text { Skor: } 68.63 \% \text {. Ranking: baik } \\
\text { - Sebagian besar kemampuan perusahaan } \\
\text { sedang untuk memproduksi produk baru } \\
\text { tergantung contoh produk, gambar teknik } \\
\text { dan SDM yang ada } \\
\text { - Perusahaan akan memajang, meng- } \\
\text { gunakan brosur, dan internet untuk } \\
\text { memasarkan produk } \\
\text { - Pengaruh adanya rancangan produk baru } \\
\text { sangat besar terhadap perusahaan } \\
\text { sehingga trial akan dilakukan secara terus } \\
\text { menerus dan melihat prospek ke depan. }\end{array}$ & $\begin{array}{l}\text { - Pengenalan produk baru kepada konsumen } \\
\text { dapat dilakukan dengan semenarik } \\
\text { mungkin } \\
\text { - Dalam memproduksi produk baru, } \\
\text { perusahaan harus melihat tanggapan dari } \\
\text { konsumen, manfaat dan fungsinya } \\
\text { - Produk baru diharapkan dapat diterima } \\
\text { oleh masyarakat dan memiliki keunggulan } \\
\text { dibanding produk lama. }\end{array}$ \\
\hline 3 & $\begin{array}{l}\text { Kemampuan } \\
\text { reaksi (R) } \\
0,416\end{array}$ & $\begin{array}{l}\text { Pengenalan yang } \\
\text { bervariasi (r1) } \\
\text { Nilai prioritas: } \\
0,0948\end{array}$ & $\begin{array}{l}\text { Skor: } 61,96 \% \text {. Ranking: baik } \\
\text { - Sebagian besar perusahaan cepat untuk } \\
\text { memproduksi produk yang bervariasi } \\
\text { - Menerima permintaan produk yang } \\
\text { bervariasi sesuai kemampuan fasilitas } \\
\text { perusahaan } \\
\text { - Berusaha menyelesaikan produk } \\
\text { menggunakan mesin yang ada }\end{array}$ & $\begin{array}{l}\text { - Perusahaan harus mampu memenuhi } \\
\text { keinginan pelanggan karena persaingan } \\
\text { yang semakin ketat untuk mendapatkan } \\
\text { kepercayaan konsumen } \\
\text { - Permintaan produk yang semakin } \\
\text { bervariasi pada kondisi pasar yang tidak } \\
\text { tentu menuntut perusahaan manufaktur } \\
\text { untuk beradaptasi terhadap perubahan } \\
\text { yang terjadi dengan cepat. }\end{array}$ \\
\hline 4 & $\begin{array}{l}\text { Kualitas produk } \\
\text { (Q) } \\
0,262\end{array}$ & $\begin{array}{l}\text { Kualitas produk } \\
\text { akhir (q3) } \\
\text { Nilai prioritas: } \\
0,0930\end{array}$ & $\begin{array}{l}\text { Skor: } 76,08 \% \text {. Ranking: baik } \\
99 \% \text { perusahaan mengatakan bahwa } \\
\text { hanya 1-10\% produk yang dihasilkan cacat. } \\
\text { Jadi kualitas produk akhir industri cor } \\
\text { logam sangat baik. } \\
\text { Kecacatan produk akhir biasanya terjadi } \\
\text { karena kurang kehati-hatian pekerja dan } \\
\text { kekroposan produk. } \\
\text { Produk akhir yang cacat akan dilebur } \\
\text { kembali oleh perusahaan. }\end{array}$ & $\begin{array}{l}\text { - Kualitas produk akhir harus diperhatikan } \\
\text { karena mempunyai nilai jual yang tinggi } \\
\text { bagi kepuasan pelanggan. } \\
\text { - Produk akhir yang baik tidak hanya tidak } \\
\text { memiliki cacat, tetapi memiliki standar dari } \\
\text { perusahaan bahkan Standar Nasional } \\
\text { Indonesia (SNI) sehingga ada jaminan } \\
\text { terhadap produk yang dijual. }\end{array}$ \\
\hline 5 & $\begin{array}{l}\text { Kualitas produk } \\
\text { (Q) } \\
0,262\end{array}$ & $\begin{array}{l}\text { Kualitas proses } \\
\text { (q2) } \\
\text { Nilai prioritas: } \\
0,0881\end{array}$ & $\begin{array}{l}\text { Skor: } 72,94 \% \text {. Ranking: baik } \\
\text { - Pemeriksaan kualitas pada proses produksi } \\
\text { sering dilakukan oleh operator baik dari } \\
\text { segi suhu logam cair, bentuk dan fungsi. } \\
\text { - Sekitar 51-75\% SOP dilaksanakan dalam } \\
\text { proses produksi }\end{array}$ & $\begin{array}{l}\text { - Kualitas dalam proses perlu diperhatikan } \\
\text { karena dapat mempengaruhi kualitas } \\
\text { produk akhir. } \\
\text { - Pemeriksaan dan pengawasan saat proses } \\
\text { harus dilakukan secara terus menerus } \\
\text { - SOP harus dilaksanakan dengan baik agar } \\
\text { hasilnya sesuai standar yang ditetapkan. }\end{array}$ \\
\hline 6 & $\begin{array}{l}\text { Kualitas produk } \\
\text { (Q) } \\
0,262\end{array}$ & $\begin{array}{l}\text { Kualitas bahan } \\
\text { baku (q1) } \\
\text { Nilai prioritas: } \\
0,0808\end{array}$ & $\begin{array}{l}\text { Skor: } 66,47 \% \text {. Ranking: baik } \\
\text { - Bahan baku yang digunakan adalah Fero } \\
\text { dan non Fero } \\
\text { - Kualitas bahan baku pada industri cor } \\
\text { logam sudah sangat baik. } 99 \% \text { perusahaan } \\
\text { mengatakan bahwa } 71-100 \% \text { bahan baku } \\
\text { yang dibeli lolos pengujian dengan kualitas } \\
\text { baik. } \\
\text { - Alat untuk pengujian bahan baku } \\
\text { menggunakan spectrometer }\end{array}$ & $\begin{array}{l}\text { - Pemeriksaan material dapat dilakukan: } \\
\text { a. Pengujian kekerasan (menggunakan metode } \\
\text { Brinell, Rockwell, Vickers dan Shore) } \\
\text { b. Pengujian tarik } \\
\text { c. Pengujian analisa kimia (spektrometri, } \\
\text { EDS) } \\
\text { d. Pengujian struktur mikro dan struktur } \\
\text { makro. } \\
\text { - Bahan baku dapat diambil dari produk } \\
\text { perusahaan yang cacat sehingga kualitas } \\
\text { material tetap terjaga. }\end{array}$ \\
\hline
\end{tabular}


Sedangkan untuk kemampuan cerdas dari prioritas 11 sampai dengan 16 merupakan ciri-ciri CMS. Kendala dari latar belakang pendidikan tenaga kerja, modal, pengelompokkan cell, CMS tidak tepat digunakan dalam industri cor logam Ceper. Walaupun CMS juga memperpendek lead time tetapi tidak cukup fleksibel untuk memproduksi produk baru, adanya pembatasan pada pengenalan sebuah produk baru karena potensi operasional yang tidak sama dengan produk yang ada, fleksibilitas rendah untuk variasi produk, dan tidak ekonomis untuk menuntut fluktuasi baik jenis atau volume.

\section{Simpulan}

Dari empat kriteria yang berpengaruh dalam pemilihan sistem manufaktur pada sentra industri cor logam Ceper, kriteria daya tanggap atau kemampuan reaksi menempati prioritas tertinggi, diikuti kriteria kualitas produk, biaya produk, ketrampilan operator, dan persediaan. Berdasarkan prioritas ini maka strategi sistem manufaktur yang sesuai dengan kondisi lingkungan adalah dengan mengadopsi strategi LMS dibandingkan dengan keadaan aktual yang lebih cenderung menerapkan strategi DMS. Strategi usulan yang diharapkan dapat berpotensi mewujudkan kecerdasan dalam organisasi perusahaan disajikan dalam Tabel 8.

\section{Ucapan Terima Kasih}

Naskah ini merupakan ringkasan dari laporan akhir hasil kegiatan penelitian skim Hibah Bersaing dari tahun 2009-2011. Oleh karena itu, kami sampaikan banyak terima kasih kepada Direktorat Penelitian Dan Pengabdian Kepada Masyarakat, Direktorat Jenderal Pendidikan Tinggi, Kementerian Pendidikan dan Kebudayaan, yang telah memberikan kepercayaan dan bantuan pendanaan kepada tim kami. Di samping itu, kami juga mengucapkan terimakasih kepada Dr. Hossein Sharifi dari Management School The University of Liverpool United Kingdom, yang telah memberikan ijin dan bersedia mengirimkan kuesioner versi penuh untuk digunakan sebagai alat pengukuran dalam penelitian ini.

\section{Daftar Pustaka}

1. Abdi, M. R., and Labib, A. W., A Design Strategy for Reconfigurable Manufacturing Systems (RMSs) Using Analytical Hierarchical Process (AHP), International Journal of Production Research, 41(10), 2003, pp. 2273-2299.

2. Elkins, D. A., Huang, N., and Alden, J.M., Agile Manufacturing Systems in the Automotive Industry, International Journal of Production Economics, 91, 2003, pp. 201-214.

3. Emiracle, Dedicated Manufacturing Systems, 2010. retrieved from http://www.vrl-kcip.org, on 30 June 2010.

4. Kompas, Industri Cor Logam Ceper Makin Parah, 28 Juni 2004, hlm. 17.

5. Kompas, Ekonomi Rakyat di Titik Nadir, 29 Februari 2008, hlm. 19.

6. Putri, R., Lean Manufacturing pada Sistem Produksi Toyota, 2007, retrieved from http:// www.managementfile.com, on 31 May 2010.

7. Radar Solo, Kritisnya Sektor Riil, 27 Agustus, 2005, hlm. 5.

8. Saaty, T. L., Multicriteria Decision Making-The Analytic Hierarchy Process, McGraw-Hill, New York, 1988.

9. Sanchez, A. M., and Perez, M. P., Lean Indicator and Manufacturing Strategies, International Journal of Operations Production Management, 21(11), 2001, pp. 1433-1451.

10. Sharifi, H., and Zhang, Z., Agile Manufacturing in Practice: Application of A Methodology", International Journal of Operations and Production Management, 21(5/6), 2001, pp. 772-794.

11. Siliconfearest, Cellular Manufacturing System, 2003, retrieved from http://www. siliconfareast. com/cellular-manufacturing.htm, on 6 June 2010.

12. Singh, N., and Rajamani, D., Cellular Manufacturing Systems, First Edition, Chapman \& Hall, London, 1996.

13. Taj, S., Applying Lean Assessment Tools in Chinese Hi-tech Industries, Management Decision, 43(4), 2005, pp. 628-643.

14. Yusuf, Y. Y, Sarhadi, M. and Gunasekaran, A., Agile Manufacturing: The Drivers, Concepts and Attributes, International Journal of Production Economics, 62, 1999, 33-43. 